\title{
Correlation of Chronic Kidney Disease with Cardiomegaly Imaging in Posteroanterior Chest X-ray
}

\author{
Pradiba Amadita* \\ Faculty of Medicine \\ Jenderal Achmad Yani University \\ Cimahi, Indonesia \\ *pradibaamadita@gmail.com
}

\author{
Priatna \\ Department of Radiology \\ Jenderal Achmad Yani University \\ Cimahi, Indonesia
}

\author{
Hendri Priyadi \\ Department of Internal Medicine \\ Jenderal Achmad Yani University \\ Cimahi, Indonesia
}

\begin{abstract}
Chronic kidney disease (CKD) is a health problem which prevalence is still high and one of the causes of cardiovascular complications. One of those cardiovascular complications is cardiomegaly. One way to identify cardiomegaly is by measuring the cardiothoracic ratio (CTR) in chest $x$-ray (CXR). The aim of this study is to see correlation, if any, of CKD and the cardiomegaly imaging in posteroanterior (PA) CXR. This was an observational analytic study with comparative crosssectional design. The total sample was 60 people who was divided into 2 groups, 30 people with CKD and 30 people without CKD who were taken by consecutive sampling technique. The data was analysed descriptively then followed by Chi-Square Test with 95\% confidence interval. The results showed that 30 people $(\mathbf{1 0 0 \%})$ were classified into stage 5 of CKD. Cardiomegaly was detected in 22 people $(73.3 \%$ ), the mean CTR was $60 \%, 22$ people $(73.3 \%)$ showed left ventricle enlargement, 20 people $(66.7 \%)$ showed left atrium enlargement, and 7 people $(23.3 \%)$ showed all chambers enlargement. There was a significant correlation between CKD and cardiomegaly ( $p=0.001$ and $P R=2.57$ ).
\end{abstract}

Keywords - cardiomegaly, chest $x$-ray, chronic kidney disease

\section{INTRODUCTION}

Chronic kidney disease (CKD) is a serious health problem that is still growing in the global population [1]. CKD will cause complications such as hypertension, anemia, and uremic state $[1,2]$. Cardiovascular abnormalities commonly encountered in patients with CKD. Left ventricle (LV) pressure overload occurs frequently from hypertension and LV volume overload occurs as a result of the presence of anemia and hypervolemia [2-4]. Cardiovascular complications are a major cause of morbidity and mortality in CKD patients, accounting for approximately $50 \%$ of deaths [4]. Several studies have shown that LV enlargement and congestive heart failure have higher mortality than coronary disease in subjects with CKD [2-4].
It is clear that accelerated cardiovascular disease (CVD) is prevalent in subjects with CKD. One example of the CVD is cardiomegaly [5,6]. As CKD progresses, the prevalence of cardiomegaly increases, and by CKD stage 5 , prior to initiation of renal replacement therapy, about $70-90 \%$ of patients exhibit cardiomegaly with varying degrees of severity $[2,5,7]$.

Cardiomegaly can be detected using electrocardiogram (ECG), echocardiography, and chest x-ray (CXR). Although echocardiography is considered to be the gold standard for diagnosing cardiomegaly, its availability is still limited, expensive and requires trained experts [8,9]. The posteroanterior (PA) CXR is the most common imaging used as a reliable alternative as it is a widely available tool in medical facilities $[8,9]$.

There was still a little study reported about CKD and its effect on cardiomegaly imaging in CXR. Therefore, we would like to assess the correlation of CKD with the prevalence of cardiomegaly using CXR as an alternative instrument.

\section{METHODS}

\section{A. Study Population and Sample Size}

This is a comparative cross-sectional study. The data was collected from 60 medical records. We divided the subjects into 2 groups: 30 subjects in group with CKD and 30 subjects in group without CKD but had CKD risk factors such as hypertension and diabetes mellitus. The sample was taken consecutively. This study complies with the Declaration of Helsinki and was approved by the local Ethics Committee.

\section{B. Measurements}

We collected the demographic data and medical history from the medical records. Patients' age and serum creatinine 
were collected and used to measure estimated glomerular filtration rate (eGFR) using CKD-Epi creatinine formula. Chest X-ray (CXR) result used to calculate the CTR and examine cardiac chamber enlargement, the latter validated by at least 2 radiologists.

\section{Inclusion and Exclusion Criteria}

1) Inclusion criteria: 1) From the medical record, the subject was diagnosed with CKD by an internist, 2) CKD-Epi creatinine measurement shown eGFR $\leq 90 \mathrm{ml} / \mathrm{min} / 1.73 \mathrm{~m}^{2}, 3$ ) has undergone CXR with posteroanterior position.

2) Exclusion criteria: 1) Subjects with heart condition(s) prior to being diagnosed with CKD, 2) CXR taken in anteroposterior position, 3) difficulty to determine heart contour, 4) scoliosis vertebrae, 5) rib cage distortion.

\section{Statistical Analysis}

The data was analysed by the Statistical Package for the Social Sciences software version 15.0 (SPSS Inc. Chicago, IL, USA). Qualitative data was expressed as number and percentage, that are analysed by the chi-square test. Quantitative data was presented as mean. The risk factors associated with different CKD stages. A $P$-value of less than 0.05 was considered as statistically significant.

\section{RESULTS}

In this study, we enrolled 60 subjects that were consecutively selected. The subjects then divided into 2 groups, first group was subjects with CKD and second group was subjects without CKD but has hypertension and/or diabetes mellitus as comorbid(s). Table 1 shows the baseline characteristics of them. Of the total study population, $40.0 \%$ were males and $60 \%$ were females, mean age was 50.40 years old and all of them were classified as CKD stage V.

\section{A. GFR and CKD Stages}

Decrease of kidney function can be measured by decrease of GFR. We measured eGFR using the CKD-Epi creatinine formula. Table 2 shows the mean of serum creatinine and mean eGFR in the study. The mean of serum creatinine was 9.2 $\mathrm{mg} / \mathrm{dl}$ with eGFR after calculation was $6.1 \mathrm{ml} / \mathrm{min} / 1.73 \mathrm{~m}^{2}$. From the eGFR measurement, we classified the subjects' CKD stage and all of them were classified as CKD stage V.

\section{B. Cardiomegaly Prevalence in CKD Subjects}

We examine the CTR in posteroanterior CXR in subjects with CKD. Table 3 shows the percentage of cardiomegaly. It shows that $73.3 \%$ of subjects have cardiomegaly and $26.7 \%$ show no cardiomegaly image in the CXR.
TABLE I.

DEMOGRAPHIC CHARACTERISTICS OF SUBJECTS WITH CKD

\begin{tabular}{|c|c|c|}
\hline \multirow{2}{*}{ Variable } & \multicolumn{2}{|r|}{ Total } \\
\hline & $n$ & Percentage (\%) \\
\hline \multicolumn{3}{|c|}{ Sex } \\
\hline Male & 12 & 40.0 \\
\hline Female & 18 & 60.0 \\
\hline \multicolumn{3}{|c|}{ Age (years) } \\
\hline Mean & 50.40 & \\
\hline Median & 46.50 & \\
\hline Range & $24-84$ & \\
\hline \multicolumn{3}{|l|}{ CKD Stage* } \\
\hline 5 & 30 & $100 \%$ \\
\hline
\end{tabular}

*CKD classified into 5 stages; stage 0 : eGFR $>90 \mathrm{~mL} / \mathrm{min} / 1.73 \mathrm{~m}^{2}$, no proteinuria, and normal kidney function; stage 1: eGFR $>90 \mathrm{~mL} / \mathrm{min} / 1.73 \mathrm{~m}^{2}$ with evidence of kidney damage; stage 2: eGFR $60-89$ $\mathrm{mL} / \mathrm{min} / 1.73 \mathrm{~m}^{2}$, mild decrease in GFR; stage 3: eGFR $30-59 \mathrm{~mL} / \mathrm{min} / 1.73 \mathrm{~m}^{2}$, moderate decrease in GFR; stage 4: eGFR $15-29 \mathrm{~mL} / \mathrm{min} / 1.73 \mathrm{~m}^{2}$, severe decrease in GFR; and stage 5: eGFR <15 $\mathrm{mL} / \mathrm{min} / 1.73 \mathrm{~m}^{2}$ or in dialysis, kidney failure.

TABLE II. SERUM CREATININE AND EGFR OF SUBJECTS WITH CKD

\begin{tabular}{|l|l|l|c|}
\hline Variable & Mean & Median & Range \\
\hline Serum creatinine $(\mathrm{mg} / \mathrm{dl})$ & 9.2 & 7.9 & $3.1-19.6$ \\
\hline eGFR $\left(\mathrm{ml} / \mathrm{min} / 1.73 \mathrm{~m}^{2}\right) *$ & 6.1 & 5.75 & $2.5-14.4$ \\
\hline \multicolumn{4}{|c}{$*$ eGFR measured using CKD-Epi creatinine formula }
\end{tabular}

\section{CTR and Cardiac Chamber Enlargement Imaging}

Regarding to the radiological findings, we get the mean CTR was $60 \%$. Out of $73.3 \%$ of subjects with cardiomegaly (Table 4), all of them have suffered left ventricle enlargement, $66.7 \%$ with the enlargement has progressed to left atrial, and $23.3 \%$ has suffered all chambers enlargement (Table 5).

TABLE III. CARdiomegaly PREVAlEnCE IN SubJeCts With CKD

$\mid$\begin{tabular}{|l|l|l|}
\hline \multirow{2}{*}{ Variable } & \multicolumn{2}{|c|}{ Total } \\
\cline { 2 - 3 } & $\boldsymbol{N}$ & $\boldsymbol{\%}$ \\
\hline Cardiomegaly* & 22 & 73.3 \\
\hline No cardiomegaly & 8 & 26.7 \\
\hline Total & 30 & 100 \\
\hline
\end{tabular}
*Cardiomegaly defines as cardiothoracic ratio (CTR) $\geq 50 \%$ in CXR

TABLE IV. MEAN CTR ON SUBJECTS WITH CARDIOMEGALY IMAGING

\begin{tabular}{|l|l|l|c|}
\hline & Mean & Median & Range \\
\hline CTR (\%) & 60.0 & 62.77 & $50.0-73.0$ \\
\hline
\end{tabular}

TABLE V. CARDIAC CHAMBER ENLARGEMENT SHOWN IN CXR OF SUBJECTS WITH CKD

\begin{tabular}{|l|l|l|l|}
\hline \multicolumn{2}{|c|}{} & \multicolumn{2}{|c|}{ Total } \\
\cline { 3 - 4 } & & $\boldsymbol{n}$ & $\boldsymbol{\%}$ \\
\hline Enlargement & Left atrium & 20 & 66.7 \\
\hline & Left ventricle & 22 & 73.3 \\
\hline & All chambers & 7 & 23.3 \\
\hline No enlargement & & 8 & 26.7 \\
\hline
\end{tabular}

\section{Correlation of CKD and Cardiomegaly}

Bivariate analysis was done to analyse the correlation of cardiomegaly and CKD. We compare the cardiomegaly number seen in the first group (subjects with CKD) with the second group (subjects without CKD but have hypertension and/or diabetes mellitus). The result on Table 6 shows that $\mathrm{CKD}$ is significantly correlated with the presence of 
cardiomegaly (prevalence risk (PR), 2.57; 95\% confidence interval $(\mathrm{CI}), \mathrm{p}=0.001)$.

TABLE VI. CORRELATION OF CKD AND CARDIOMEGALY BASED ON CHISQUARE TEST

\begin{tabular}{|c|c|c|c|c|c|c|}
\hline & \multicolumn{2}{|c|}{ CKD } & \multicolumn{2}{|c|}{ No CKD } & \multirow{2}{*}{$\begin{array}{c}\mathbf{P R}^{*} \\
\left(\mathbf{C I}^{\dagger} 95 \%\right)\end{array}$} & \multirow{2}{*}{ P value } \\
\hline & $n$ & $\%$ & $n$ & $\%$ & & \\
\hline Cardiomegaly & 22 & 73.3 & 9 & 30.0 & 2.57 & 0.001 \\
\hline No cardiomegaly & 8 & 26.7 & 21 & 70.0 & $(1.37-4.84)$ & \\
\hline Total & 30 & 100 & 30 & 100 & & \\
\hline
\end{tabular}

\section{DISCUSSION}

From this study, prevalence of CKD occurred more in females, because in menopause females the protective factor of estrogen has decrease [10]. Decrease of kidney perfusion and increase in kidney vascular resistance happened more in females with hyperglycaemia rather than in males [10]. Although the CKD prevalence is higher in females, the decrease of GFR is more progressive in males [10,11]. In this study, the CKD prevalence is higher in our elderly subjects with age mean is 50,40 years old and like other similar studies, most patients diagnosed with CKD are in the age range of 5059 years old $[8,9]$. Aging undergoes several changes in body that impact kidney function, so GFR declines with age [12].

The decrease in GFR indicates worsening kidney function and the worse complication that arise from it. Prevalence to suffer cardiomegaly increase in patients with CKD stage 3-5 (pre-dialysis) [3,5]. There were different findings in this study from previous studies, which all of the subjects in this study are classified as CKD stage 5. Generally, CKD symptoms will not present until the late stage (stage 4-5) when the metabolism and hormonal disorder and electrolyte imbalance become more severe and it will lead patients to go to the hospital $[12,13]$.

As seen in the results, $73.3 \%$ of the CKD subjects already suffered cardiomegaly with left ventricle enlargement. From the CXR, 23.3\% has shown all cardiac chambers enlargement and $66.7 \%$ has also shown left atrial enlargement. Pressure and volume overload caused by CKD will cause compensation mechanisms [4,14]. But if the compensation happened for a long time, it would turn into decompensation of heart muscle. Uremic state also contributes to worsening the condition. If not treated properly, heart failure has higher mortality than coronary disease in CKD patients $[4,15,16]$.

Prevalence of cardiomegaly correlates with degree of kidney injury. Kidney injury will cause complications such as renal hypertension, chronic anemia, and uremic syndrome which will add cardiac workload that eventually will cause cardiac structural changes [4,16,17]. This study shows significant correlation $(\mathrm{p}=0.001)$ with prevalence risk $(\mathrm{PR})$ 2.57. It means patients with CKD are 2.57 times more at risk to suffer cardiomegaly.

\section{StUdy Limitation}

Not all CKD subjects underwent CXR examination because CXR was not a mandatory examination for CKD patients. Chronic kidney disease (CKD) patients that underwent CXR were only patients on late stage with pulmonary edema as a complication or other pulmonary disease. Because all the subjects were CKD stage 5, the results of this study were not describing general conditions of CKD patients.

\section{CONCLUSION}

We conclude that CKD prevalence is higher in female and elderly patients. Most of the subjects had cardiomegaly with signs of left ventricle enlargement. CKD is significantly correlated with the prevalence of cardiomegaly.

\section{REFERENCES}

[1] Kementerian Kesehatan Republik Indonesia (Kemenkes RI), Riset Kesehatan Dasar. Jakarta: Kemenkes RI, 2013.

[2] Indonesian renal Registry, 5 th Report Of Indonesian Renal Registry 2012. Progr Indones Ren Regist [Online]. Retrieved from: http://www.pernefri-inasn.org/Laporan/5thAnnualReportOfIRR 2012.pdf, 2012.

[3] L. Di Lullo, A. Gorini, D. Russo, A. Santoboni and C. Ronco, "Left ventricular hypertrophy in chronic kidney disease patients: from pathophysiology to treatment," Cardiorenal medicine, vol. 5, no. (4), pp. 254-266, 2015.

[4] E. Alhaj, N. Alhaj, I. Rahman, T.O. Niazi, R. Berkowitz and M. Klapholz, "Uremic cardiomyopathy: an underdiagnosed disease," Congestive heart failure, vol. 19, no. (4), pp. E40-E45, 2013.

[5] E.L. Schiffrin, M.L. Lipman and J.F. Mann, "Chronic kidney disease: effects on the cardiovascular system," Circulation, vol. 116, no. (1), pp. 85-97, 2007.

[6] S.L. Robbins, R.S. Cotran, V. Kumar, A.K. Abbas, N. Fausto and J.C Aster, "Robbins and Cotran pathologic basis of disease," In Robbins and Cotran pathologic basis of disease, pp. 1450-1450, 2010.

[7] A.G. Stack, H. Serna, A. Ramsanahie and C. Henry, "Determinants and prognostic importance of cardiomegaly among new ESRD patients in the United States," Annals of epidemiology, vol. 14, no. (9), pp. 676$685,2004$.

[8] F.D.A. Costa, R.M.D.S. Póvoa, A.F.P. Costa, M.A.M.D. Silva, I.R Rivera, C.R.C. Ferro and V.C.D. Lima, "Left ventricular mass and cardiothoracic index in patients with chronic renal disease on hemodialysis," Brazilian Journal of Nephrology, vol. 36, pp. 171-175, 2014.

[9] S. Manjuri, D. Dhiraj, K. Santosh and D.H. Jyoti, "Clinical study of cardiovascular complications in chronic kidney disease patients with special reference to echocardiography," Chest, vol. 9, pp. 18, 2016.

[10] I. Goldberg and I. Krause, "The role of gender in chronic kidney disease," Emj, vol. 1, no. (2), pp. 58-64, 2016.

[11] S. Tjekyan, "Prevalensi dan faktor risiko penyakit ginjal kronik di RSUP Dr. Mohammad Hoesin Palembang tahun 2012," Majalah Kedokteran Sriwijaya, vol. 46, no. (4), pp. 275-281, 2014.

[12] F. Poluan, C. Sugeng and E. Surachmanto, "Profil pasien penyakit ginjal kronik yang dirawat di RSUP Prof. Dr. RD Kandou Manado periode Juni 2014-Juli 2015," e-CliniC, vol. 4, no. (1), 2016.

[13] N.R. Hill, S.T. Fatoba, J.L. Oke, J.A. Hirst, C.A. O’Callaghan, D.S Lasserson and F.R. Hobbs, "Global prevalence of chronic kidney disease-a systematic review and meta-analysis," PloS one, vol. 11, no. (7), pp. e0158765, 2016. 
[14] National Kidney Foundation (NKF), KDOQI Clinical practice guidelines for chronic kidney disease: evaluation, classification, and stratification. New York: NKF, 2002.

[15] K. Suwitra, Penyakit ginjal kronik. Dalam Sudoyo. Jakarta: Buku Ajar Ilmu Penyakit Dalam, 2014.

[16] R.J. Glassock, R. Pecoits-Filho and S.H. Barberato, "Left ventricular mass in chronic kidney disease and ESRD," Clinical Journal of the
American Society of Nephrology, vol. 4, no. (Supplement 1), pp. S79S91, 2009.

[17] R.J. Glassock, R. Pecoits-Filho and S. Barbareto, "Increased left ventricular mass in chronic kidney disease and end-stage renal disease: what are the implications?" Dialysis \& Transplantation, vol. 39, no. (1), pp. 16-19, 2010. 